https://doi.org/10.18485/iipe_postkovid.2021.ch5

\title{
EVROPSKA UNIJA I PANDEMIJA VIRUSA KOVID 19 - NEPOSREDNI ODGOVOR I DUGOROČNE MERE ZA PRILAGOĐAVANJE BUDUĆIM KRIZAMA
}

\begin{abstract}
Ana JOVIĆ LAZIĆ 1
Sanja JELISAVAC TROŠIĆ

Apstrakt: Pandemija virusa Kovid 19 izazvala je neočekivanu globalnu krizu sa dalekosežnim posledicama po zdravstveni, društveni i ekonomski sistem većine zemalja. Početni odgovor Evropske unije bio je prilično neorganizovan, što se, između ostalog, odrazilo kroz nekoordinisano sprovođenje blokada ili nedostatak solidarnosti država članica u pogledu nabavke medicinske i zaštitne opreme. lako je ovaj rani odgovor na pandemiju otkrio nedostatak spremnosti, kohezije i solidarnosti unutar Unije, situacija se u međuvremenu značajno poboljšala, s tim što su neki korisni instrumenti uvedeni na nivou EU. Cilj ovog rada je da istraži odgovor Unije na krizu, kao i političke i ekonomske implikacije pandemije na institucije, politike i akcije EU. Kakav je uticaj pandemija imala na politički sistem Evropske unije i koje je mere ona preduzela da odgovori na krizu i prilagodi se novoj situaciji? Osnovna hipoteza je da, iako je kriza predstavljala veliki izazov za EU, njen naknadni odgovor na pandemiju pokazuje da je ona pronašla političku volju i način da obnovi saradnju i koheziju na nadnacionalnom nivou. S obzirom na to da se lekcije naučene tokom kriza mogu koristiti za sprovođenje mera potrebnih za unapređenje procesa evropskih integracija, očekuje se da će kriza izazvana pandemijom otvoriti mogućnosti za bližu saradnju među državama
\end{abstract}

\footnotetext{
${ }^{1}$ Viši naučni saradnik, Institut za međunarodnu politiku i privredu, Beograd, Srbija. E-mail: anajovic@diplomacy.bg.ac.rs;

Rad je nastao u okviru naučnoistraživačkog projekta „Srbija i izazovi u međunarodnim odnosima 2021. godine", koji finansira Ministarstvo prosvete, nauke i tehnološkog razvoja Republike Srbije, a realizuje Institut za međunarodnu politiku i privredu tokom 2021. godine, Beograd.

${ }^{2}$ Viši naučni saradnik, Institut za međunarodnu politiku i privredu, Beograd, Srbija. E-mail: sanja@diplomacy.bg.ac.rs
} 
članicama. Ovo je od velikog značaja jer je ova, pre svega, zdravstvena kriza dovela do posledične društveno-ekonomske krize, dovodeći u pitanje same temelje i osnovne principe na kojima je zasnovana EU.

Ključne reči: Evropska unija, pandemija Kovid 19, odgovor na krizu, prilagodljivost.

\section{Uvodne napomene}

Kriza izazvana širenjem virusa Kovid 19 razlikuje se od prethodnih po tome što je uticala na zdravstvene, političke, bezbednosne i ekonomske sisteme skoro svih država sveta. ${ }^{3}$ Zbog svog globalnog karaktera pandemija je imala dalekosežne posledice po međunarodne odnose, utičući ne samo na stepen saradnje između država, već i na oblikovanje unutrašnjeg odgovora mnogih međunarodnih organizacija. Ni Evropska unija nije ostala imuna na ovu krizu. Štaviše, ova kriza je za Uniju predstavljala veliki izazov zbog njene nadnacionalne specifičnosti i ekonomskih, političkih i institucionalnih struktura koje iz toga proističu. Testirala je sposobnost EU da reaguje brzo i efikasno, kako bi umanjila ekonomske i socijalne efekte pandemije na države članice EU. Konkretno, početna zabrinutost zbog pandemije uzrokovane nedovoljno poznatim virusom dovela je do niza neusklađenih koraka država članica. U svakom slučaju, većina vlada preduzela je mere da smanji prenos bolesti i opterećenje svojih zdravstvenih sistema. Došlo je do jednostranog zatvaranja granica, što je ograničilo unutrašnju trgovinu čak i neophodnom zaštitnom medicinskom opremom, ali je takođe uticalo na slobodu kretanja, ljudska prava i demokratiju. Ovo je poljuljalo veru u evropski projekat, pokazujući slabost Unije i njenu nesposobnost da, na nadnacionalnom nivou, blagovremeno i adekvatno odgovori na novonastalu situaciju. Nadnacionalne institucije i njihov način rada bili su pod velikim pritiskom i izgledalo je da nisu u stanju da izvedu EU iz poteškoća izazvanih pandemijom. Unija i njene države članice suočile su se sa izazovima koji su pokrenuli niz strateških pitanja, uključujući i to kako bi EU mogla postati otpornija na buduće krize. Krize se smatraju značajnima jer često dovode do određenih promena i prilagođavanja na nivou EU. Jedan od

\footnotetext{
${ }^{3}$ Sanja Jelisavac Trošić, Ana Jović-Lazić, „Ekonomske posledice COVID-19 i mere podrške privredi Republike Srbije", Zarazne bolesti kao globalni bezbednosni izazov - Pandemija COVID-19: stvarnost i posledice, Zoran Jeftić i Mihailo Kopanja (urs), Fakultet bezbednosti, Institut za međunarodnu politiku i privredu, 2020, str. 94-118.
} 
osnivača evropskih integracija, Žan Mone, izjavio je da će „Evropa biti iskovana u krizama i biće zbir rešenja koja su usvojena za te krize“." $U$ poslednjih deset godina Unija se suočila sa nekoliko kriza, uključujući krizu evrozone, migrantsku krizu i pitanje Bregzita, koje su bile razlog zabrinutosti u pogledu budućeg pravca procesa evropskih integracija. Ipak, EU je uspela da na njih, više ili manje, uspešno odgovori i ponovo uspostavi unutrašnju ravnotežu.

Za razliku od prethodnih, kriza izazvana pandemijom virusa Kovid 19 otvorila je pitanja sposobnosti i kapaciteta EU da upravlja vanrednim situacijama u oblasti zdravstva, i spremnosti država članica da zajedno rade na rešavanju sličnih globalnih izazova. ${ }^{5}$ Takođe je imala vrlo specifičan uticaj na Uniju, jer je počela kao kriza javnog zdravlja, a zatim postala složen problem koji pogađa brojne oblasti saradnje država članica, ukazujući na određene nedostatke u njenim institucionalnim i organizacionim kapacitetima. Uniji nije bilo lako da, na principima solidarnosti, uspostavi koordinisan odgovor na pandemiju i društveno-ekonomske probleme koji su usledili. Međutim, pokazalo se da poseduje određenu vrstu otpornosti, kao i da je, u odnosu na prethodne krize, reagovala relativno brže i organizovanije. Tako su početne neusklađenosti, vremenom zamenjene spontanim usaglašavanjem propisa država članica i postepenim prihvatanjem uloge Komisije kao koordinatora nacionalnih politika. Ublažavanje i usaglašavanje nacionalnih odgovora na pandemiju bilo je neophodno kako bi smanjila negativna prelivanja unutar Unije i neravnotežu u ekonomskim i zdravstvenim sistemima država članica.

$\mathrm{U}$ ovom radu se ispituje odgovor Unije na krizu izazvanu širenjem virusa Kovid 19 i uticaj pandemije na njene institucije, politike i akcije. Time se nastoji odgovoriti na pitanja koje korake je Unija preduzela da odgovori na pandemiju i prilagodi se novoj situaciji, kao i da li je ona iskoristila krizu da proširi svoje aktivnosti, kao i opseg i instrumente svojih politika.

Da bi se to postiglo, prvo se kritički analiziraju početne reakcije država članica i same Unije na pandemiju. Zatim se daje pregled konkretnih mera i

\footnotetext{
${ }^{4}$ J. Monnet 1978. Memoirs. trans. R. Mayne Garden City: Doubleday \& Company, Navedeno prema: Gerda Falkner, "The EU's current crisis and its policy effects: research design and comparative findings", Journal of European Integration, 38:3, 2016, pp. 219-235.

${ }^{5}$ Eugenio Salvati, "Crisis and Intergovernmental Retrenchment in the European Union? Framing the EU's Answer to the COVID-19 Pandemic", Chinese Political Science Review, Springer, 2021, No. 6, pp. 1-19.
} 
aktivnosti, sprovedenih na nivou EU, u cilju upravljanja ovom krizom i nastojanja da se uspostavi jedinstven evropski okvir delovanja. Konačno, ukazuje se na osnovu u evropskom zakonodavstvu koja je omogućila odgovor EU na ovu, pre svega, zdravstvenu krizu, kao i na odluke, mere i politike koje su nakon izbijanja pandemije preduzete na nivou Unije, a koje bi trebalo da ojačaju njenu otpornost i kapacitete da adekvatno odgovori u slučaju budućih sličnih kriza.

\section{Kritike, izazovi i ograničenja odgovora Evropske unije na pandemiju}

Prve reakcije država članica i Evropske unije na širenje pandemije virusa Kovid 19 bile su predmet velikih kritika, ukazujući na izazove i ograničenja sa kojima se, pre svega, suočila Evropska unija. Kako se priznaje i u samom uvodu Izveštaja Evropske komisije o aktivnostima EU za 2020. „odgovor EU na pandemiju Kovid 19 doveo je do ljudske tragedije, zaključavanja i ekonomskog usporavanja bez presedana". ${ }^{6}$ Uopšteno govoreći, nepredvidivost i karakter pandemije, kao i neorganizovani i haotični odgovori država članica, uz nedostatak međusobne saradnje i kapaciteta EU, imali su ozbiljan uticaj ne samo na Uniju već i na percepciju nje i njenih vrednosti u široj međunarodnoj zajednici. To nije bio dobar pokazatelj za evropske integracije, a s obzirom na institucionalnu strukturu Unije, koja uključuje donošenje odluka na nekoliko nivoa, postavila su se pitanja - ko je za to odgovoran i da li su mogle i trebale biti donete drugačije odluke? ${ }^{7}$

Kada je pandemija izazvana virusom Kovid 19 pogodila Evropu, Unija je, kao i ostatak sveta, bila gotovo potpuno paralizovana. Da bi se izborile sa krizom, vlade država članica preduzele su odvojene i međusobno nekoordinisane korake bez konsultacija sa EU. Ove nacionalne odluke uglavnom su bile motivisane strahom jer su se vlade borile da zaštite stanovništvo, spreče slom zdravstvenih sistema, a da pritom očuvaju

\footnotetext{
6 "The EU in 2020 - General Report on the Activities of the European Union", European Commission, 15 February 2021, C(2021) 1002, Luxembourg: Publications Office of the European Union, 2021, p. 13.

7 Sarah Wolff and Stella Ladi, "European Union Responses to the Covid-19 Pandemic: adaptability in times of Permanent Emergency", Journal of European Integration, 2020, p. 1030.
} 
preduzeća, industriju i radna mesta. lako su postojale značajne razlike u načinu upravljanja pandemijom i efikasnosti primenjenih strategija, sve države su odmah uvele niz vanrednih mera kako bi ograničile širenje virusa.

Opsežne blokade uvedene kako bi se sprečilo širenje virusa neizbežno su ograničile slobodu kretanja, ali i mnoga druga osnovna načela i prava uspostavljena na nivou EU, poput principa jedinstvenog tržišta i utvrđenih šengenskih normi. Istovremeno, pandemija je bila neka vrsta lakmus testa za nacionalne zdravstvene sisteme, koja je otkrila značajne razlike u opremi i kapacitetima država članica da odgovore na ovu krizu. ${ }^{8}$ Razorne posledice koje je pandemija ostavila u Italiji ukazale su na negativne efekte koje su oštre mere štednje, uvedene nakon krize u evrozoni, imale na socijalnu potrošnju, što je, između ostalog, uticalo na zdravstvo. ${ }^{9}$ Istovremeno, javio se primetan nedostatak kohezije i jedinstva među članicama EU. Neke države članice EU uvele su ograničenja na izvoz lične zaštitne opreme, dok su se druge osećale nesigurno i napušteno gubeći veru u evropsko jedinstvo i solidarnost. ${ }^{10}$ Uprkos pozivima na jedinstvo, nedostatak saradnje i protekcionizam na evropskom nivou bili su očigledni. Kada je Italija zatražila pomoć u medicinskoj i zaštitnoj opremi, evropskim partnerima trebalo je više vremena da je obezbede nego Kini ili Rusiji. ${ }^{11}$ Naime, kada je krajem januara 2020. Italija zatražila hitan sastanak, Savetu ministara zdravlja trebalo je dve nedelje da se okupi nakon čega je data izjava o prihvatljivom nivou spremnosti EU da odgovori na predstojeću krizu, bez postizanja dogovora o konkretnim merama koje u tom smislu treba sprovesti. ${ }^{12}$

${ }^{8}$ Charlotte Beaucillon, "European Solidarity in Times of Emergency: An Introduction to the Special Focus on COVID-19 and the EU", European Papers, Vol. 5, 2020, No 1, p. 688.

${ }^{9}$ Giuseppe Celi, Dario Guarascio, Annamaria Simonazzi, "A fragile and divided European Union meets Covid-19: further disintegration or 'Hamiltonian moment'?", Journal of Industrial and Business Economics, 47, pp. 411-424.

${ }^{10}$ Nicu Popescu, "How the coronavirus threatens a geopolitical Europe", European Council on Foreign Relations, 30 March 2020, https://ecfr.eu/article/commentary_how_the _coronavirus_threatens_a_geopolitical_europe/.

11 "Geopolitics after Covid-19: is the pandemic a turning point?", http://country.eiu. com/article. aspx?articleid=1219299705\&Country=Hungary\&topic=Politics\&subtopic $=$ =Forecast\&subsubtopic=International+relations?zid=covid_daily_14/04/2020.

12 Anne-Laure Beaussier and Lydie Cabane, "Strengthening the EU's Response Capacity to Health Emergencies: Insights from EU Crisis Management Mechanisms", European Journal of Risk Regulation, Vol. 11:4, 2020, p. 812. 
Pomoć koju su Rusija i Kina pružale Italiji privukla je veliku pažnju medija i dovela do javnih kritika Unije. Na taj način je nanela štetu „mekoj moći“ EU i pogoršala već rasprostranjenu „,krizu solidarnosti“, zbog čega je Unija, posebno na početku pandemije, najviše osporavana. To je razumljivo, s obzirom na to da je solidarnost, kao ključni princip i vrednost Unije koju dele njene članice, ugrađen u član 2 Ugovora o EU i u Povelju EU o osnovnim pravima, i član 222 Ugovora o funkcionisanju EU. Dakle, solidarnost kao politički princip i vrednost EU zasnovana je na konceptu saradnje i uzajamne pomoći u slučaju krize koja pogađa jednu državu članicu, ali potencijalno može da utiče na sve njih. Zbog toga se odgovor EU na bilo koju krizu, uključujući i krizu izazvanu pandemijom, procenjuje kroz prizmu solidarnosti, što je jedno od ključnih kriterijuma na osnovu kojih se meri neuspeh ili uspeh Unije. ${ }^{13}$

S obzirom na to da je ovu krizu bilo teško predvideti i da je njen karakter univerzalan, prvi meseci pandemije ukazali su na ograničenja trenutnih aranžmana na nivou EU. Salvati (Salvati) ističe da je prvobitni odgovor Unije ometen i nedostatkom institucionalnih kapaciteta i kredibiliteta, kao i nemogućnošću da se obezbedi autonomni proces političkog odlučivanja. lako bi u slučaju pandemijskih, i sličnih zdravstvenih, kriza ona trebalo da ima organizacione i političke instrumente neophodne za brzo donošenje odluka, koji bi joj omogućili pristup resursima potrebnim za sprovođenje odgovarajućih politika, evropske institucije pokazale su se kao nedovoljno fleksibilne i prilično teške za manevrisanje. ${ }^{14}$ Tako npr. Bruks i Gejerb (Brooks and Geyerb) ističu da Mehanizam EU za civilnu zaštitu nije mogao pravovremeno da odgovori, jer nije mogao da se nosi sa zahtevima za istim sredstvima koja su dolazila od svih država članica istovremeno. Jednostavno on nije ni bio osmišljen da odgovori na ovu vrstu univerzalne krize. ${ }^{15}$ Samadašvili (Samadashvili) ističe i da su odgovori vlada predstavljali ozbiljan izazov zakonodavstvu EU, jer su prevedeni u nacionalna pravila sa različitim stepenom primene od strane država članica, imali značajan prekogranični uticaj. Nije bilo lako uspostaviti efikasan i

${ }^{13}$ Charlotte Beaucillon, "European Solidarity in Times of Emergency: An Introduction to the Special Focus on COVID-19 and the EU", op. cit., p. 688.

${ }^{14}$ Eugenio Salvati, "Crisis and Intergovernmental Retrenchment in the European Union? Framing the EU's Answer to the COVID-19 Pandemic", op. cit.

${ }^{15}$ Eleanor Brooks and Robert Geyerb, "The development of EU health policy and the Covid19 pandemic: trends and implications", Journal of European Integration, 2020, Vol. 42, No. 8, p. 1058. 
jedinstven odgovor na nivou EU, jer je on zahtevao od država članica da priznaju Komisiju kao koordinatora pojedinačnih nacionalnih inicijativa, kao i da sarađuju u složenom procesu donošenja odluka koji zahteva konsenzus. ${ }^{16}$ $\mathrm{U}$ ovim uslovima postojao je rizik da nadnacionalne institucije budu dodatno marginalizovane ili oslabljene u poređenju sa nacionalnim, kao i da to za posledicu ima smanjenje političke i ekonomske solidarnosti na nivou Unije. ${ }^{17}$

Postoje mišljenja da je, zbog specifične prirode Unije, njeno učešće određeno ovlašćenjima EU u oblasti zdravstva koja su prilično ograničena. To je rezultat nastojanja država članica da zadrže autonomiju nad nacionalnim zdravstvenim politikama i sistemima. ${ }^{18} \mathrm{~S}$ druge strane, postoje i mišljenja da to nije neizbežna posledica ograničenih nadležnosti EU, kao i da bi nadležnost Unije u oblasti javnog zdravstva trebalo tumačiti zajedno sa drugim pravnim osnovama vezanim za zdravlje, a ne izolovano. ${ }^{19}$ Dakle, iako nema ovlašćenja da usvaja regulativu s primarnim ciljem usklađivanja nacionalnih definicija zdravstvene politike, kao i organizacije i pružanja zdravstvenih usluga i lečenja, evropsko zakonodavstvo Uniji daje mnoge nadležnosti koje proširuju njena zakonska ovlašćenja izvan posebnih normi direktnih nadležnosti. ${ }^{20}$ Pravni osnov i okvir za odgovor EU na zdravstvene krize predmet su posebnog podnaslova, o čemu će biti reči kasnije.

Pandemija nije izazvala samo krizu u oblasti javnog zdravlja, već je dovela do velikih ekonomskih poremećaja i značajnog pada ekonomskih aktivnosti, zbog čega su se mnoge kompanije suočile sa problemima likvidnosti. Finansijska tržišta pokazala su se kao izuzetno nestabilna, što je dovelo do

${ }^{16}$ Salome Samadashvili, A brave, post-COVID-19 Europe, European View, 1/9, 2020, pp. 3-4.

${ }^{17}$ Eugenio Salvati, "Crisis and Intergovernmental Retrenchment in the European Union? Framing the EU's Answer to the COVID-19 Pandemic", op. cit.

${ }^{18}$ Anne-Laure Beaussier and Lydie Cabane, "Strengthening the EU's Response Capacity to Health Emergencies: Insights from EU Crisis Management Mechanisms", op. cit., p. 812.

${ }^{19}$ Alberto Alemanno, "The European Response to COVID-19 From Regulatory Emulation to Regulatory Coordination?", European Journal of Risk Regulation, Vol. 11:2, pp. 308-309.

${ }^{20}$ Kai P. Purnhagen, Anniek De Ruijter, Mark L. Flear, Tamara K. Hervey and Alexia Herwig, "More Competences than You Knew? The Web of Health Competence for European Union Action in Response to the COVID-19 Outbreak", European Journal of Risk Regulation, Vol. 11:2, 2020, pp. 298-300. 
povećane nezaposlenosti i siromaštva. U tim okolnostima, države članice su primenile različite nacionalne politike što je dovelo do velikih rashoda $u$ njihovim budžetima. Različiti fiskalni kapaciteti država članica za pružanje finansijske podrške i raznolikost mera na nacionalnom nivou pretili su da ugroze jedinstveno tržište, kao i unutrašnju koheziju EU. ${ }^{21}$

Kriza izazvana širenjem virusa Kovid 19 ugrozila je ne samo zdravstvene sisteme i ekonomiju EU, već i stanje njene demokratije. U nastojanju da spreče njegovo širenje, vlade država članica uvele su mere poput karantina, prinudnog fizičkog distanciranja i mera zaštite, koje su ograničile slobodu kretanja, javnog okupljanja, pravo na rad, privatni i porodični život. Stav Unije je da konvencije o ljudskim pravima, poput Evropske konvencije o ljudskim pravima, moraju da se primenjuju i u slučaju pandemije. Tim pre što je članom 15 ove konvencije predviđeno da, u slučaju vanrednih situacija, države potpisnice mogu privremeno odstupiti od nekih obaveza predviđenih konvencijom ukoliko za to postoje uslovi. Dakle, ovaj član državi ne daje neograničena prava u vanrednim situacijama, već ograničava prirodu i opseg predviđenog odstupanja. ${ }^{22}$ lako su mnoge od uvedenih mera opravdane, imajući u vidu karakter i opseg pandemije, javila se zabrinutost da bi vlade nekih država članica mogle iskoristiti ovu krizu da podriju i ograniče građanska i ljudska prava uopšte. Zbog toga su postala sve glasnija mišljenja da vlade moraju obezbediti da takve mere budu privremene, kao i da budu podložne redovnom preispitivanju kako bi bile srazmerne legitimnim ciljevima u oblasti javnog zdravstva. ${ }^{23}$ Od sredine marta 2020. Komisija prati mere u državama članicama koje utiču na vladavinu prava, demokratiju i osnovna prava. U preporukama Saveta za svaku državu članicu ponaosob iz avgusta 2020. podseća se da one moraju biti srazmerne i vremenski ograničene. ${ }^{24}$ Tim pitanjem se bavi Saopštenje Evropske komisije o vladavini

21 “Council Regulation (EU) 2020/2094 of 14 December 2020 establishing a European Union Recovery Instrument to support the recovery in the aftermath of the COVID-19 crisis", Official Journal of the European Union, L 433I, 22 December 2020, Vol. 63.

${ }^{22}$ Anja Rađenovic and Gianna Eckert, "Upholding human rights in Europe during the pandemic", Briefing, European Parliamentary Research Service, PE 652.085 - September 2020.

23 "Europe at a crossroads: Dos and don'ts for authorities when responding to the COVID19 pandemic"; April 2020, Amnesty International, https://www.amnesty.org/download/ Documents/EUR0120792020ENGLISH.PDF

24 "I Resolutions, recommendations and opinions, Recommendations, Council,", Official Journal of the European Union, C 282/1, 26.8.2020, Vol. 63. 
prava, kao i Rezolucija Evropskog parlamenta o uticaju mera koronavirusa na demokratiju, vladavinu prava i osnovna prava. ${ }^{25}$

Kada je u nastojanju da odgovori na ekonomske poremećaje, kao i da obezbedi poštovanje vladavine prava od strane država članica, EU ponudila određene instrumente i mehanizme za prevazilaženje posledica pandemije, ispoljene su velike razlike u mišljenjima država članica. Nakon što su Francuska i Nemačka predstavile plan ekonomskog oporavka, Holandija, Danska, Švedska i Austrija su se, u prvom momentu, usprotivile pružanju pomoći najteže pogođenim članicama. ${ }^{26}$ Dogovor je ipak postignut što je bila velika pobeda za Uniju. Međutim, nije izvesno da će efekti ovog programa pomoći biti dugoročni. Naime, uprkos značajnom budžetskom podsticaju koji bi trebao da dovede do jače kohezije država članica, postoji zabrinutost da bi, kao rezultat pandemije i recesije, ekonomske neravnoteže u Uniji mogle da se povećaju. Takođe, pre nego što je konačno postignut dogovor o ovom opsežnom paketu ekonomskih podsticaja koji se finansira zajedničkim zaduživanjem, Mađarska i Poljska su nedeljama blokirale budžetski paket, jer je Unija predvidela novi mehanizam koji povlačenje sredstava iz Fonda za oporavak od krize uslovljava poštovanjem vladavine prava.

\section{Konkretne mere i aktivnosti Evropske unije preduzete kao odgovor na pandemiju}

Inicijalni odgovor EU na pandemiju izgledao je neskladno i nedosledno, pre svega zbog mera na nacionalnom nivou koje su usvojile države članice. Bez obzira na to, EU je ubrzo sprovela niz inicijativa kako bi što bolje upravljala ovom

\footnotetext{
25 "2020 Rule of Law Report The rule of law situation in the European Union COM/2020/580 final", Communication from the Commission to the European Parliament, the Council, the European Economic and Social committee and the Committee of the Regions, https://eur-lex.europa.eu/legal-content/EN/TXT/HTML/?uri=CELEX:52020DC0580\& from=EN; "European Parliament Resolution of 13 November 2020 on the impact of COVID-19 measures on democracy, the rule of law and fundamental rights", 2020/ 2790(RSP), https://www.europarl.europa.eu/doceo/document/TA-9-2020-0307_EN.pdf.

${ }^{26}$ Maria Josepha Debre, Hylke Dijkstra, "COVID-19 and Policy Responses by International Organizations: Crisis of Liberal International Order or Window of Opportunity?", Global Policy, 2021, pp. 1-12.
} 
krizom, kako na zdravstvenom tako i na ekonomskom planu. lako, posebno u početnim fazama krize, one nisu uspele da adekvatno odgovore na potrebe i zahteve država članica, od velikog su značaja jer su pokazatelji kapaciteta kojim raspolaže Unija i svakako će uticati na uvođenje novih i prilagođavanje postojećih instrumenata, inicijativa i mehanizama politike EU.

Kako bi pružila konzularnu podršku građanima koji se vraćaju u EU, Komisija je 28. januara 2020. pokrenula Mehanizam EU za civilnu zaštitu. Istog dana, hrvatsko predsedavanje Savetom EU pokrenulo je Mehanizam za integrisani politički odgovor na krizu u vidu razmene informacija, a 2. marta 2020. odlučeno je da se on prebaci na potpuno operativni režim. ${ }^{27} \mathrm{~S}$ obzirom na to da EU putem ovog mehanizma organizuje politički odgovor na krizu na najvišem nivou, to je omogućilo organizaciju sastanaka sa zvaničnicima institucija EU radi dogovora o konkretnim merama.

Još u izveštaju Evropskog centra za prevenciju i kontrolu bolesti od 25. januara 2020. procenjeno je da se, u svetlu tada dostupnih informacija, smatra da je potencijalni uticaj virusa Kovid 19 veliki i da je verovatno njegovo dalje globalno širenje. ${ }^{28} \mathrm{U}$ zaključcima usvojenim nakon sastanka Saveta, održanog 13. februara 2020, takođe je prepoznata opasnost od izbijanja pandemije i pozvano na veću saradnju EU i drugih država i međunarodnih organizacija. Pored toga, istaknuto je da bi EU i njene države članice trebalo da koordinišu aktivnosti i usko sarađuju na polju zdravstvene zaštite, sprovode mere planiranja, reagovanja i pripravnosti, u skladu sa Odlukom EU o ozbiljnim prekograničnim pretnjama po zdravlje i Mehanizmom EU za civilnu zaštitu u oblasti vanrednih situacija. Istaknut je i značaj rada Evropskog centara za kontrolu i prevenciju bolesti na tehničkim smernicama u vezi sa analizom, procenom rizika, lečenjem zaraženih, zaštitom zdravstvenih radnika, kao i značaj rada Evropske agencije za lekove, na tretmanima, vakcinama i istraživanjima. ${ }^{29} \mathrm{U}$ martu 2020. osnovan je i savetodavni panel Komisije o Kovid

\footnotetext{
27 "European reaction to the outbreak of Coronavirus (COVID-19)", 2020, https:// www.europeansources.info/record/european-reaction-to-the-outbreak-of-coronavirus/.

28 "Communicable Disease Threats Report", 25 January 2020, European Centre for Disease Prevention and Control (ECDC), https://www.ecdc.europa.eu/sites/default/files/ documents/communicable-disease-threats-report-25-jan-2020-PUBLIC.pdf, p. 8.

29 "Council Conclusions on COVID-19", Council of the European Union, Brussels, 13 February 2020, https://data.consilium.europa.eu/doc/document/ST-6038-2020-INIT/ en/pdf.
} 
19, kao ad hoc savetodavno stručno telo sastavljeno od epidemiologa i virusologa iz različitih država članica, a kojim predsedava predsednik Komisije. ${ }^{30}$

Pandemija je uticala kako na trgovinu sa drugim državama tako i na slobodno kretanje robe unutar EU i normalno funkcionisanje jedinstvenog tržišta. Kada se javio značajan nedostatak lične zaštitne opreme, lekova i medicinskih sredstava širom EU, Unija nije mogla odmah da odgovori na ovu situaciju. Ipak, uspela je da preduzme određene korake kako bi državama članicama omogućila pristup ovoj opremi. Tako su u martu i aprilu 2020. usvojena privremena izvozna ograničenja na njen izvoz van EU, koja su trajala do 25. maja 2020. ${ }^{31}$ Takođe, da bi se omogućilo Uniji da interveniše u slučaju vanrednih stanja u javnom zdravstvu, Uredbom od 30. marta 2020. izmenjen je Fond solidarnosti EU, osnovan 2002. za pružanje pomoći državama članicama nakon velikih prirodnih katastrofa. Izmenama je, između ostalog, omogućeno EU da pruži podršku državama članicama u cilju sprovođenja hitnih mera usmerenih na zaštitu stanovništva od mogućih javnih zdravstvenih rizika, uključujući prevenciju širenja zaraznih bolesti. ${ }^{32}$

Ubrzo, Komisija je sprovela zajednički postupak nabavke lične zaštitne opreme i donela odluku da pod Mehanizmom EU za civilnu zaštitu, napravi strateške zalihe medicinske opreme u okviru rescEU sistema. Komisija je takođe uspostavila mehanizam za razmenu lične zaštitne opreme, s ciljem koordinacije napora da se usklade ponuda i potražnja u EU i omogući pravilno

30 "European Commission's advisory panel on COVID-19", https://ec.europa.eu/health/ advisorypanel_covid19_en.

31 "Commission Implementing Regulation (EU) 2020/402 of 14 March 2020 making the exportation of certain products subject to the production of an export authorization"; "Commission Implementing Regulation (EU) 2020/426 of 19 March 2020 amending Implementing Regulation (EU) 2020/402 making the exportation of certain products subject to the production of an export authorisation C/2020/1864", Official Journal of the European Union L 84I, 20 March 2020, Vol. 63; "Commission Implementing Regulation (EU) 2020/568 of 23 April 2020 making the exportation of certain products subject to the production of an export authorization", Official Journal of the European Union, L 129/7, 24 April 2020, Vol. 63.

32 "Regulation (EU) 2020/461 of the European Parliament and of the Council of 30 March 2020 amending Council Regulation (EC) No 2012/2002 in order to provide financial assistance to Member States and to countries negotiating their accession to the Union that are seriously affected by a major public health emergency", Official Journal of the European Union, L 99/9, 31 March 2020, Vol. 63. 
funkcionisanje unutrašnjeg tržišta. ${ }^{33}$ Pored toga, usvojila je smernice o optimalnoj i racionalnoj nabavci lekova kako bi se izbegla nestašica tokom pandemije $^{34}$ i radila je na uklanjanju nacionalnih izvoznih ograničenja i drugih prepreka slobodnom kretanju medicinske opreme i lekova unutar EU. ${ }^{35}$ Mehanizam EU za civilnu zaštitu korišćen je, početkom aprila 2020, za raspoređivanje evropskih medicinskih timova u Italiju, kojim je upravljao Koordinacioni centar za hitno reagovanje. ${ }^{36}$

Tokom sastanka, održanog 26. marta 2020, članovi Evropskog saveta obavezali su se da će učiniti sve što je moguće kako bi zaštitili građane EU i prevazišli krizu, podržavajući evropske vrednosti i način života. Osim hitnosti borbe protiv pandemije i njenih neposrednih posledica, pozvali su na razvoj koraka koji će biti neophodni za ponovno normalno funkcionisanje evropskog društva, ekonomija i njihov održivi rast. Na osnovu ovih preporuka 17. aprila 2020. usvojena je Zajednička evropska mapa puta ka ukidanju mera za suzbijanje Kovid 19. ${ }^{37}$ Sredinom narednog meseca usvojeno je Saopštenje Komisije prema faznom i koordinisanom pristupu za obnavljanje slobode kretanja i ukidanje kontrola na unutrašnjim granicama. ${ }^{38}$

Kako bi se ojačali zdravstveni sistemi i povećala spremnost EU za moguće nove talase pandemije, 10. jula 2020. usvojena je Rezolucija Evropskog

33 "COVID-19 Clearing House for medical equipment", https://ec.europa.eu/info/live-worktravel-eu/coronavirus-response/emergency-support-instrument/covid-19-clearinghouse-medical-equipment_en.

34 "Guidelines on the optimal and rational supply of medicines to avoid shortages during the COVID-19 outbreak", Communication from the Commission, https://ec.europa.eu/ info/sites/default/files/communication-commission-guidelines-optimal-rational-supplymedicines-avoid.pdf 8.4.2020.

35 "Commission Decision (EU) 2020/491 of 3 April 2020 on relief from import duties and VAT exemption on importation granted for goods needed to combat the effects of the COVID-19 outbreak during 2020 (notified under document C(2020) 2146)".

36 "Coronavirus: EU Medical Teams deployed to Italy, European Commission", Press release, 7 April 2020, Brussels, https://ec.europa.eu/commission/presscorner/detail /en/ip_20_613.

37 "Joint European Roadmap towards lifting COVID-19 containment measures", Official Journal of the European Union, 17.4.2020, C 126/1.

38 "Towards a phased and coordinated approach for restoring freedom of movement and lifting internal border controls - COVID-19", Communication from the Commission 2020/C 169/030J : JOC_2020_169_R_0003 
parlamenta o strategiji EU za javno zdravlje nakon Kovida 19. ${ }^{39}$ Pet dana kasnije, 15. jula 2020, usvojeno je Saopštenje Komisije o zdravstvenoj spremnosti EU za brzi odgovor u slučaju ponovnog rasplamsavanja pandemije Kovid $19 .{ }^{40}$ Dva dana kasnije, 17. jula 2020, Komisija je predstavila Strategiju EU za vakcine, kako bi ubrzala razvoj i proizvodnju vakcina protiv Kovid 19. Ova strategija ima za cilj da obezbedi dovoljnu proizvodnju vakcina u EU, a samim tim i dovoljno zaliha za države članice na osnovu ugovora o prethodnoj kupovini sa proizvođačima u okviru Instrumenta hitne podrške. ${ }^{41}$ Strategija predviđa prilagođavanje regulatornog okvira Unije aktuelnoj krizi i korišćenje postojeće regulatorne fleksibilnosti za ubrzanje razvoja, odobravanja i dostupnosti vakcina, uz očuvanje standarda kvaliteta, bezbednosti i efikasnosti. ${ }^{42}$ Dakle, pored zajedničke kupovine medicinske opreme, upravljanja trgovinom i otvaranja granica, saradnja EU proširena je na podršku razvoju, testiranju i proizvodnji vakcina, kao i dijagnostici i lečenju bolesti izazvanih virusom Kovid 19. Takođe, kako bi se ojačala otpornost EU na prekogranične zdravstvene pretnje, Komisija je 11. novembra 2020. godine izdala saopštenje u kojem su iznete ideje i predlozi za stvaranje Evropske zdravstvene unije. ${ }^{43}$

39 "European Parliament Resolution of 10 July 2020 on the EU's public health strategy post-COVID-19 (2020/2691(RSP))".

40 "Short-term EU health preparedness for COVID-19 outbreaks", Communication from the Commission to the European parliament, the Council, the European Economic and Social Committee and the Committee of the Regions, Brussels, 15.7.2020, COM(2020) 318 final.

${ }^{41}$ Ovaj instrument objedinjuje napore, resurse i stavlja na raspolaganje dodatna finansijska sredstva za zajedničke strateške potrebe. Na osnovu principa solidarnosti, pomaže u ublažavanju neposrednih posledica pandemije i predviđanju potreba povezanih sa oporavkom od krize. "The Emergency Support Instrument", https://ec.europa.eu/info /live-work-travel-eu/coronavirus-response/emergency-support-instrument_en.

42 "EU Strategy for COVID-19 vaccines", Communication from the Commission to the European Parliament, the European Council, the Council and the European Investment Bank, COM/2020/245 final, Brussels, 17.6.2020, https://eur-lex.europa.eu/legal-content /EN/TXT/?qid=1597339415327\&uri=CELEX:52020DC0245.

43 "Building a European Health Union: Reinforcing the EU's resilience for cross-border health threats", Communication from the Commission to the European Parliament, the Council, the European Economic and Social Committee and the Committee of the Regions, European Commission, Brussels, 11.11.2020. COM(2020) 724 final, https://ec. europa.eu/info/sites/default/files/communication-european-health-union-resilience_ en.pdf. 
Osim zdravstvene krize, pandemija virusa Kovid 19 pokrenula je recesiju koja je uzrokovala visoke ekonomske i socijalne troškove širom Evropske unije. Zahvaljujući nadležnostima u ovim sektorima, Unija je imala mogućnosti da odgovori na socioekonomske efekte pandemije. Takođe, nakon krize u evrozoni EU je uvela efikasne instrumente koji mogu podržati države članice i obezbediti stabilnost finansijskih tržišta, tako da je Unija iskoristila prethodno iskustvo i odgovorila instrumentima kojima raspolaže.

Evropska unija je brzo krenula u mobilizaciju resursa kako bi pronašla rešenja za ekonomsku krizu izazvanu pandemijom. Činjenica da je pandemija izazvala veliki ekonomski šok koji se ogleda kroz poremećaje u globalnim lancima snabdevanja, nestabilnost na finansijskim tržištima, smanjenu potražnju, udare na pojedine privredne sektore i likvidnost preduzeća prepoznata je još u Saopštenju Komisije od 13. marta 2020. o koordinisanom ekonomskom odgovoru na Kovid 19. U ovom dokumentu ističe se značaj solidarnosti, usklađenog i jasnog zajedničkog pristupa za suzbijanje negativnih ekonomskih posledica pandemije. $U$ tom cilju se navodi niz interventnih mera Komisije u cilju ublažavanja neposrednih ekonomskih posledica Kovida 19. U nastojanju da očuva ekonomsku i finansijsku stabilnost, EU je ublažila propise o državnoj pomoći kako bi se omogućilo da vlade država članica sredstvima iz budžeta pruže ekonomsku pomoć, pre svega, malim i srednjim preduzećima i tako pomognu očuvanju radnih mesta. ${ }^{44}$

lako je to pomoglo nacionalnim vladama da samostalno organizuju početne reakcije na krizu, budući da je pandemija imala različit uticaj na ekonomije država članica, to je povećalo rizik od daljeg širenja jaza unutar Unije. Naime, države članice EU imaju različite finansijske kapacitete da intervenišu u svoje privrede, što je doveo do strahovanja da bi to moglo da stvori asimetriju među državama članicama, jer bi one sa najviše novca, tj. sa većim kapacitetom za zaduživanje i potrošnjom, mogle steći značajnu prednost na jedinstvenom tržištu EU što bi moglo negativno utiče na dostignuti nivo integracije. ${ }^{45}$ Međutim, EU je brzo prepoznala ove opasnosti i činjenicu da one

44 "Coordinated economic response to the COVID-19 Outbreak", Communication from the Commission, Brussels, 13.3.2020 COM(2020) 112 final, https://ec.europa.eu/info/ sites/default/files/communication-coordinated-economic-response-covid19-march2020 en.pdf.

${ }^{45}$ Giuseppe Celi, Dario Guarascio, Annamaria Simonazzi, "A fragile and divided European Union meets Covid-19: further disintegration or 'Hamiltonian moment'?", op. cit.; 
zahtevaju koherentan i jedinstven pristup. Kao rezultat toga, početkom aprila 2020, na nivou Unije postignut je dogovor o paketu od 540 milijardi evra kako bi se tokom pandemije pomoglo radnicima, firmama i državama članicama. Od toga, 100 milijardi evra dodeljeno je za očuvanje radnih mesta kroz Evropski instrument za privremenu podršku za ublažavanje rizika od nezaposlenosti u hitnim slučajevima, 200 milijardi evra Panevropskom garantnom fondu za kreditiranje preduzeća od strane Evropske investicione banke, a 240 milijardi evra državama članicama putem Evropskog mehanizama za stabilnost. ${ }^{46}$ Pored toga, lideri EU postigli su 23. aprila 2020. dogovor da rade na uspostavljanju Fonda za oporavak EU kako bi ublažili posledice krize izazvane pandemijom. Tom prilikom Komisija je pozvana da uradi analizu konkretnih potreba i podnese predlog koji će povezati ovaj fond i dugoročni budžet Unije. ${ }^{47}$ Saopštenjem pod naslovom - „Evropa na delu: oporavak i priprema za sledeću generaciju“, Komisija je 27. maja 2020. predložila novi instrument za oporavak od 750 milijardi evra. Predloženo je da ovaj instrument, nazvan „Sledeća generacija EU” bude deo predstojećeg budžeta EU. ${ }^{48}$ Nakon toga, 21. jula 2020. lideri EU sastali su se u Briselu kako razgovarali o paketu za oporavak od 750 milijardi evra. Osim paketa za oporavak, čelnici EU razgovarali su o višegodišnjem finansijskom okviru EU od 1.074 milijarde evra za period od 2021. do 2027. ${ }^{49}$ Dakle, evropski lideri su shvatili da su moraju da rade zajedno kako bi pomogli EU u rešavanju problema izazvanih pandemijom, što je

Eugenio Salvati, "Crisis and Intergovernmental Retrenchment in the European Union? Framing the EU's Answer to the COVID-19 Pandemic", op. cit., pp. 1-19.

46 "COVID-19: the EU's response to the economic fallout", https://www.consilium.europa. eu/en/policies/ coronavirus/covid-19-economy/.

47 "Conclusions of the President of the European Council following the video conference of the members of the European Council", 23 April 2020, European Council Statements and remarks", 23 April 2020, https://www.consilium.europa.eu/en/press/pressreleases/2020/04/23/conclusions-by-president-charles-michel-following-the-videoconference-with-members-of-the-european-council-on-23-april-2020/.

48 "Communication from the Commission to the European Parliament, the European Council, the Council, the European Economic and Social Committee and the Committee of the Regions, Europe's moment: Repair and Prepare for the Next Generation", European Commission, Brussels, 27.5.2020, COM(2020) 456 final.

49 "Special meeting of the European Council (17, 18, 19, 20 and 21 July 2020) Conclusions, European Council, Brussels, 21 July 2020 (OR. en) EUCO 10/20", https://www.consilium.europa.eu/media/45109/210720-euco-final-conclusions-en.pdf. 
omogućilo EU da postigne koordinisaniji odgovor u suočavanju sa krizom koronavirusa nego što je to bio slučaj u prethodnim krizama.

Na sastanku Evropskog saveta 10. i 11. decembra 2020, države članice su se složile da će podržati višegodišnji finansijski okvir za period 2021-2027. i paket za oporavak od krize izazvane Kovidom 19. ${ }^{50}$ Uredbom od 14. decembra 2020. uspostavljen je Instrument oporavka Evropske unije za period od 2021. do 2027. godine, kojim je EU dobila mogućnost da na finansijskim tržištima pozajmljuje sredstva u ukupnom iznosu od 750 milijardi evra, što rezultira zajedničkim dugom. ${ }^{51}$ Nakon odobrenja Evropskog parlamenta, Savet je 17. decembra 2020. usvojio niz odluka o zakonodavnim aktima koji su deo paketa i postavljaju budžetski okvir EU za naredne godine. ${ }^{52}$ Ova sredstva namenjena su državama članicama i ekonomijama koje su pandemijom ozbiljno pogođene. Prema planovima, ona će se vraćati iz sredstava EU tokom dužeg vremenskog perioda. To je veliki korak u evropskim integracijama koji pokazuje da je Unija spremna da preuzme dugoročne obaveze, i tako spreči negativne posledice koje prelivanje ekonomske i socijalne krize može imati na njenu unutrašnju koheziju.

Polazeći od toga da je kriza izazvana pandemijom, kao i ranije krize, pokazala da održivi i otporni ekonomski i socijalni sistemi mogu pomoći državama članicama da efikasnije odgovore na šokove, EU je odlučila da u okviru Instrumenta oporavka uvede Mehanizam za oporavak i otpornost. On je uveden Uredbom od 12. februara 2021. kako bi se obezbedila značajna finansijska podrška za ublažavanje negativnih efekta ekonomskih i socijalnih posledica krize izazvane pandemijom koronavirusa, a osnovni cilj je da učini ekonomiju i društvo otpornijim, održivim i pripremljenim za izazove i mogućnosti koje će doneti zelena i digitalna transformacija. Instrument za reforme i srodna ulaganja državama članicama stavlja na raspolaganju 672,5 milijardi evra, uključujući 312,5 milijardi evra grantova i 360 milijardi evra

50 "European Council meeting (10 and 11 December 2020) - Conclusions, European Council, Brussels, 11 December 2020 (OR. en), EUCO 22/20", https://www.consilium. europa.eu/media/47296/1011-12-20-euco-conclusions-en.pdf.

51 “Council Regulation (EU) 2020/2094 of 14 December 2020 establishing a European Union Recovery Instrument to support the recovery in the aftermath of the COVID-19 crisis", Official Journal of the European Union, L 433I, 22 December 2020, Vol. 63.

52 "Long-term EU budget 2021-2027 and recovery package", https://www.consilium. europa.eu/en/policies/the-eu-budget/long-term-eu-budget-2021-2027/. 
kredita. To je najveća pojedinačna inicijativa za plan oporavka, a svaka država članica mora podneti Nacionalni plan oporavka i otpornosti, u kojem su utvrđeni njihovi programi reformi i ulaganja do kraja avgusta 2026, a čiju primenu prati EU. ${ }^{53}$

Pored toga, tokom pandemije EU je prepoznala potrebu borbe sa lažnim vestima, zbog čega je 10. juna 2020. usvojeno Saopštenje Evropske komisije pod nazivom „Borba protiv dezinformacije o Kovid 19: utvrđivanje činjenica“. $\mathrm{U}$ ovom dokumentu predlaže se borba protiv dezinformacija i stranih uticaja kroz proaktivnu i pozitivnu komunikaciju, kroz postojeće instrumente EU i preko nadležnih organa država članica, civilnog društva, platformi društvenih mreža i međunarodnu saradnju. Cilj je da se poveća otpornost građana sprečavanjem da postanu žrtve lažnih informacija, koje mogu imati ozbiljne posledice, od zanemarivanja službenih zdravstvenih saveta do rizičnog ponašanja. Sprečavanje širenja dezinformacija trebalo bi, takođe, da smanji rizik od njihovog negativnog uticaja na demokratske institucije i evropsko društvo. ${ }^{54}$

Dakle, pored brojnih i često opravdanih kritika, posebno prvobitnog odgovora EU na pandemiju, evropske institucije nastojale su da se prilagode uslovima, pruže najkoherentniji mogući odgovor i razviju održiv plan za prevazilaženje ove krize. Volf i Ladi (Wolff and Ladi) veruju da je, u poređenju sa prethodnim krizama, EU brže reagovala iskoristivši postojeće krizne i institucionalne mehanizme i instrumente kako bi predvidela posledice pandemije. U tom kontekstu, preduzela je brojne korake od pružanja pomoći radnicima i preduzećima, uspostavljanja Mehanizma za oporavak i otpornost, preko uvođenja zdravstvene agende do ulaganja u vakcinu protiv koronavirusa. lako ne možemo predvideti sva buduća pitanja primene, pomenute mere pokazale su da, uz pomoć institucija EU, države članice mogu raditi zajedno na prevazilaženju izazova i posledica pandemije krize. ${ }^{55}$

53 "Regulation (EU) 2021/241 of the European Parliament and of the Council of 12 February 2021 establishing the Recovery and Resilience Facility", Official Journal of the European Union, L 57/17, 18 February 2021, Vol. 64.

54 "Joint Communication to the European Parliament, the European Council, the Council, the European Economic and Social Committee and the Committee of the Regions, Tackling COVID-19 disinformation - Getting the facts right", JOIN/2020/8 final, European Commission, Brussels, 10.6.2020.

${ }^{55}$ Sarah Wolff \& Stella Ladi, "European Union Responses to the Covid-19 Pandemic: adaptability in times of Permanent Emergency", op. cit., p. 1029. 


\section{Pravni okvir za odgovor EU na prekogranične zdravstvene pretnje i jačanje kapaciteta u ovoj oblasti}

Krize se smatraju značajnima jer često dovede do određenih promena i prilagođavanja na nivou EU. ${ }^{56}$ Posledice pandemije otvorile su pitanja o tome da li su EU i njene države članice adekvatno pripremljene za buduće slične krize, što zahteva pregled instrumenata i kapaciteta koji su u ovoj oblasti na raspolaganju EU i državama članicama.

S obzirom na to da su pitanja javnog zdravlja pre svega u nadležnosti država članica, sposobnost EU da upravlja prekograničnim zdravstvenim pretnjama se u velikoj meri oslanja na međuvladine mehanizme. Međutim, i pored mnogih ograničenja za delovanje EU u oblasti zdravstva, pravne prepreke su manje restriktivne nego što se to uobičajeno shvata i Unija ima više mogućnosti da kreira zakonodavstvo i politiku kako bi odgovorila na izbijanje pandemije. ${ }^{57}$ Hervei i de Ruijter (Hervey and de Ruijter) napominju da Unija može usvojiti obavezujuće propise usmerene na poboljšanje zdravlja, sve dok se tim merama uklanjaju trgovinske barijere ili sprečavaju značajna narušavanja konkurencije. Takođe, kažu da zakonodavstvo EU u mnogim oblastima, uključujući trgovinu, zaštitu potrošača, poljoprivredu i bezbednost, mora štititi i unapređivati zdravlje. ${ }^{58}$ Pored toga, EU ima i konkretne nadležnosti da koordiniše saradnju između država članica, kao i da pruži podršku njihovim naporima kako bi se pripremile i odgovorile na krize u oblasti javnog zdravlja. U članu 35 Povelje EU o osnovnim pravima posvećenom zdravstvenoj zaštiti, u okviru poglavlja IV posvećenog solidarnosti, navodi se da svako ima pravo na pristup preventivnoj zdravstvenoj zaštiti i pravo na lečenje u skladu sa uslovima utvrđenima nacionalnim zakonodavstvima i praksom, kao i da se pri utvrđivanju i sprovođenju svih politika i aktivnosti Unije obezbeđuje visok stepen zaštite zdravlja ljudi. ${ }^{59}$

\footnotetext{
${ }^{56}$ Ana Jović Lazić, Sanja Jelisavac Trošić, "Spoljna energetska politika Evropske unije“, Evropsko zakonodavstvo, Institut za međunarodnu politiku i privredu, god. XV, br. 55, Beograd, 2016, str. 158-170.

${ }^{57}$ Kai P. Purnhagen, Anniek De Ruijter, Mark L. Flear, Tamara K. Hervey and Alexia Herwig, "More Competences than You Knew? The Web of Health Competence for European Union Action in Response to the COVID-19 Outbreak", op. cit., pp. 298-300.

${ }^{58}$ Tamara Hervey and Anniek de Ruijter, "The Dynamic Potential of European Union Health Law", European Journal of Risk Regulation, 11(4), 2020, pp. 726-735.

59 "Charter of Fundamental Rights of the European Union", Official Journal of the European Union, C 326/391, 2012/C 326/02, 26.10.2012.
} 
Bruks i drugi (Brooks et al.) ističu da je EU imala dva ključna okvira kroz koja je, kada je izbila pandemija, organizovala odgovor na krizu koja je usledila. Prvi je kroz pravni okvir kojim se regulišu pitanja javnog zdravlja i zdravstvene bezbednosti, a drugi kroz Mehanizam civilne zaštite EU u slučaju vanrednih situacija. Ova dva osnovna okvira razvijana su u poslednje dve decenije kroz različite krize i odgovore EU na njih. Nakon širenja SARS-a, svinjskog i ptičijeg gripa, Unija je postavila mehanizme na više nivoa kako bi omogućila državama članicama saradnju i ubrzala pripremu i odgovor na slične krize. U tom kontekstu, mere koje je EU preduzela od proglašenja pandemije Kovid 19 mogu pokrenuti procese u novom pravcu, sa dugoročnim implikacijama na politiku EU u ovoj oblasti. ${ }^{60}$

Pitanju javnog zdravlja posvećen je član 168 Ugovora o funkcionisanju EU (UFEU), a u prvom stavu ovog člana navodi se da će „visok nivo zaštite zdravlja ljudi biti obezbeđen tokom definisanja i sprovođenje svih politika i aktivnosti Unije“. Osim toga, navodi se da će akcije Unije, koje će upotpuniti nacionalne politike, imati za cilj poboljšanje javnog zdravlja, sprečavanje bolesti i uklanjanje izvora opasnosti po zdravlje. Takođe, iako stav 5 ovog člana isključuje bilo kakvo usklađivanje zakona i propisa država članica u oblasti javnog zdravlja, navodi se da institucije EU „mogu ... usvojiti podsticajne mere za zaštitu i poboljšanje zdravlja ljudi, posebno za borbu protiv značajnih prekograničnih zdravstvenih pošasti, koje se odnose na praćenje, rano upozoravanje i borbu protiv ozbiljnih prekograničnih pretnji po zdravlje". U poslednjem stavu ovog člana navodi se da će delovanje „Unije poštovati odgovornosti država članica za definisanje njihove zdravstvene politike i za organizaciju i pružanje zdravstvenih usluga i medicinske nege". ${ }^{61}$ Dakle, primarna odgovornost za zdravstvenu zaštitu, a posebno za zdravstvene sisteme, ostaje na državama članicama. Međutim, EU ima važnu ulogu u podržavanju nacionalnih politika javnog zdravlja, prevenciji

\footnotetext{
${ }^{60}$ Eleanor Brooks, Anniek de Ruijter and Scott L. Greer, "Covid-19 and European Union health policy: from crisis to collective action", in: Social policy in the European Union: state of play 2020 Facing the pandemic, Bart Vanhercke, Slavina Spasova and Boris Fronteddu (eds), Brussels, 2021, p. 33; Eleanor Brooks and Robert Geyerb, "The development of EU health policy and the Covid-19 pandemic: trends and implications", Journal of European Integration, 2020, Vol. 42, No. 8, p. 1057.

61 "Consolidated version of the Treaty on the Functioning of the European Union - Part three: Union policies and internal actions - Title XIV: Public health - Article 168 (ex Article 152 TEC)", Official Journal, 115, 09.05.2008. P. 0122 - 0124.
} 
i upravljanju bolestima, ublažavanju izvora opasnosti i jačanju saradnje radi usklađivanja zdravstvenih strategija država članica. ${ }^{62}$

Još u decembru 1993. Savet je prepoznao potrebu da se na nivou Zajednice uspostavi mreža za nadzor i kontrolu zaraznih bolesti, čija bi osnovna svrha bila prikupljanje i koordinacija informacija iz nadzornih mreža u državama članicama. Pet godina kasnije uspostavljena je mreža za epidemiološki nadzor i kontrolu zaraznih bolesti u Zajednici, kako bi se koristila ne samo za epidemiološki nadzor ovih bolesti, već i za sistem ranog upozoravanja i reagovanja u cilju njihove prevencije i kontrole. ${ }^{63}$ Pomenuta mreža za epidemiološki nadzor, Uredbom od 21. aprila 2004. prerasla je u Evropski centar za prevenciju i kontrolu bolesti, koji je preuzeo epidemiološki nadzor nad zaraznim bolestima i upravljanje sistemom ranog upozoravanja i odgovora. Prema Uredbi, Evropski centar za prevenciju i kontrolu bolesti treba da pruži nezavisne naučne savete, pomoć i stručnost Zajednici putem kvalifikovanog medicinskog, naučnog i epidemiološkog osoblja iz organizacije ili priznatih tela koja deluju u ime država članica. ${ }^{64}$

Nakon razmišljanja o lekcijama stečenim tokom pandemije svinjskog gripa, oktobra 2013. doneta je Odluka o ozbiljnim prekograničnim pretnjama po zdravlje. Ona definiše ulogu nadležnih organa država članica i institucija na nivou EU u slučaju ozbiljnih prekograničnih pretnji - od planiranja, nadzora i prikupljanja podataka i procene rizika, koordinacije nacionalnih kapaciteta do aktiviranja sistema za rano upozoravanje. Predviđeno je da države članice redovno izveštavaju o svojoj pripravnosti u slučaju ozbiljnih prekograničnih zdravstvenih pretnji, kako bi o tome moglo da se diskutuje u okviru Odbora za zdravstvenu bezbednost Komisije, koji čine predstavnici ministarstava zdravlja. U slučaju aktiviranja sistema za rano upozoravanje, koji je predviđen članom 9 ove odluke, izričito se zahteva da se ovaj odbor sastane kako bi se omogućila

\footnotetext{
62 "Public health, Fact Sheets on the European Union", European Parliament https:// www.europarl.europa.eu/factsheets/en/sheet/49/public-health.

63 "Decision No 2119/98/EC of the European Parliament and of the Council of 24 September 1998 setting up a network for the epidemiological surveillance and control of communicable diseases in the Community", 3 October 1998, Official Journal, L 268, Vol. 41.

64 "Regulation (EC) No 851/2004 of the European Parliament and of the Council of 21 April 2004 establishing a European Centre for disease prevention and control", Official Journal of the European Union, 30.4.2004, L 142.
} 
razmena informacija na nacionalnom nivou i, u saradnji sa Komisijom, koordinacija mera koje treba sprovesti u smislu pripremljenosti, planiranja, informisanja i reagovanja na ozbiljnu prekograničnu pretnju. ${ }^{65}$ Godinu dana kasnije, u aprilu 2014. godine, Komisija je odobrila Sporazum o zajedničkoj nabavci, kako bi se na dobrovoljnoj bazi omogućilo svim državama članicama EU da nabavljaju pandemijske vakcine i druge medicinske protivmere kao grupa, a ne pojedinačno. Dakle, to je instrument koji je ima za cilj da, u slučaju pandemije, obezbedi dovoljne količine i pravičan pristup država članica EU vakcinama i lekovima. ${ }^{66}$

Pored pomenutog okvira, koji se na evropskom nivou bavi pitanjima javnog zdravlja i zdravstvene bezbednosti, važan instrument za odgovor EU u slučaju pandemije bio je mehanizam civilne zaštite EU u slučaju vanrednih situacija. Tako se pored člana 168 posvećenog javnom zdravlju, može se posmatrati i član 196 UFEU posvećen civilnoj zaštiti. U prvom stavu ovog člana navodi se da će Unija „podsticati saradnju država članica radi poboljšanja efikasnosti sistema za sprečavanje i zaštitu od prirodnih katastrofa ili katastrofa koje je izazvao čovek“. Dalje se navodi da će delovanje EU imati za cilj da podrži i dopuni delovanje država članica na nacionalnom, regionalnom i lokalnom nivou u sprečavanju rizika, u pripremi njihovog osoblja za civilnu zaštitu i odgovoru na katastrofe. Takođe, aktivnosti EU trebalo bi da promovišu brzu i efikasnu operativnu saradnju unutar Unije između nacionalnih službi civilne zaštite, takođe „isključujući bilo kakvo usklađivanje zakona i propisa država članica". ${ }^{67}$ Koordinacija ostaje dužnost država članica, prema članu 168 Ugovora o funkcionisanju EU, dok su instrumenti EU ograničeni na pomoćnu ulogu. Prema ovom članu UFEU, EU dopunjuje nacionalne politike javnog zdravlja

65 "Decision No 1082/2013/EU of the European Parliament and of the Council of 22 October 2013 on serious cross-border threats to health and repealing Decision No 2119/98/EC Text with EEA relevance", 5.11.2013, Official Journal of the European Union", L 293/1.

66 "European Commission, Press Release, Public Health: Joint purchasing of vaccines and medicines becomes a reality in the EU", Brussels, 10 April 2014, https://ec.europa. eu/commission/presscorner/detail/en/IP_14_418.

67 "Consolidated version of the Treaty on the Functioning of the European Union - Part Three - Union Policies and Internal Actions, Title XXIII - Civil protection, Art. 196", 7.6.2016, Official Journal of the European Union, C 202/13. 
država članica, posebno u pogledu „praćenja, ranog upozoravanja i borbe protiv značajnih prekograničnih zdravstvenih opasnosti““68

lako primarna odgovornost za sprečavanje, pripravnost i odgovor na prirodne katastrofe i katastrofe uzrokovane ljudskim delovanjem ostaje na državama članicama, 2001. osnovan je Mehanizam EU za civilnu zaštitu, u kome pored članice EU učestvuje još šest država, među kojima je i naša zemlja. Odluka o Mehanizmu civilne zaštite EU, od 17. decembra 2013, poboljšala je saradnju država članica EU, dok je istovremeno pojednostavila koordinaciju civilne zaštite. Takođe, kako bi se ojačao zajednički odgovor u slučaju vanrednih situacija, predviđeno je stvaranje dodatnih kapaciteta koji se koriste kada nacionalni kapaciteti nisu dovoljni. ${ }^{69}$ Ipak, ovaj mehanizam nije mogao adekvatno da odgovori zahtevima država članica, ukoliko se neočekivane vanredne situacije ponavljaju i dešavaju istovremeno. Zbog toga je 2019. doneta odluka da se on ojača stvaranjem rezerve dodatnih kapaciteta (RescEU) što uključuje medicinske timove i kapacitete za evakuaciju. ${ }^{70}$

Dakle, uloga EU je vremenom evoluirala tako da uključuje praćenje, rano upozoravanje i borbu protiv ozbiljnih prekograničnih zdravstvenih pretnji, dok su države članice postale obavezne da, u saradnji sa Komisijom, koordinišu svoju politiku i aktivnosti u oblastima koje pokrivaju aktivnosti u oblasti javnog zdravlja. Na taj način Unija je dobila mandat da upravlja zdravstvenim krizama sve dok se poštuju kriterijumi supsidijarnosti i proporcionalnosti. Rane faze pandemije, međutim, ukazale su na neadekvatnost postojećih kapaciteta za rešavanje hitnih zdravstvenih situacija kada one ne poznaju državne granice. Ipak, Unija je preduzela neke korake da poboljša svoj odgovor na ovu krizu i veruje se da će oni uticati na dalji razvoj njene politike u oblasti javnog zdravlja.

U okviru nastojanja da uspostavi Evropsku zdravstvenu uniju, Komisija je 11. novembra 2020. iznela predlog za uspostavljanjem novog okvira zdravstvene

\footnotetext{
${ }^{68}$ Alberto Alemanno, "The European Response to COVID-19 From Regulatory Emulation to Regulatory Coordination?", op. cit., pp. 308-309.

69 "Decision No 1313/2013/EU of the European Parliament and of the Council of 17 December 2013 on a Union Civil Protection Mechanism", Official Journal of the European Union, L 347, 20.12.2013.

70 "Decision (EU) 2019/420 of the European Parliament and of the Council of 13 March 2019 amending Decision No 1313/2013/EU on a Union Civil Protection Mechanism", Official Journal of the European Union, 20.3.2019, LI 77/1.
} 
bezbednosti koji bi ojačao ulogu Unije. Izneti predlozi imaju za cilj da, na osnovu lekcija naučenih iz pandemije Kovid 19, poboljšaju okvir zdravstvene bezbednosti EU i ulogu ključnih agencija EU u planiranju i odgovoru na buduće slične krize. U tom kontekstu, između ostalog, navodi se da bi trebalo odgovoriti na dodatne zahteve za izveštavanjem, analizom pokazatelja zdravstvenog sistema i saradnjom država članica sa Evropskim centrom za prevenciju i kontrolu bolesti. Predlaže se i jačanje kapaciteta za praćenje kontakata razvojem automatizovanog sistema koji koristi najnoviju tehnologiju, uspostavljanjem mreže referentnih laboratorija, kao i mreže koja omogućava praćenje bolesti. ${ }^{71}$ Hervej i de Rujter ističu da Unija pod svojom kontrolom ima niz podsticaja i da može omogućiti pristup resursima, opremi, stručnosti, informacijama, administrativnim kapacitetima i geopolitičkom kapitalu, što posmatrano zajedno, može značajno doprineti stvaranju Evropske zdravstvene unije. ${ }^{72}$

Kada je reč o regulativi u oblasti civilne zaštite, pandemija je takođe pokazala da Unija nije u stanju da adekvatno odgovori na iznenadne katastrofe velikih razmera, posebno kada je više država članica istovremeno pogođeno. Zbog toga je postignut dogovor o poboljšanju zakonodavnog okvira u ovoj oblasti i usvojena je Uredba o izmeni odluke o Mehanizmu EU za civilnu zaštitu, 20. maja 2021. godine. Nove odredbe, koje jačaju postojeći pravni okvir, stavljaju na raspolaganje neophodna sredstva za uspostavljanje, raspoređivanje i upravljanje kapacitetima rescEU, dalji razvoj zajedničkih evropskih fondova za civilnu zaštitu i pokrivanje dodatnih troškova. ${ }^{73}$ Takođe, u okviru višegodišnjeg finansijskog okvira EU, budžet rescEU je povećan tako da Unija raspolaže dodatnim sredstvima za brži i efikasniji odgovor u slučaju budućih sličnih kriza. ${ }^{74}$ Očekuje se da će ovo obezbediti da se nijedna država članica EU

\footnotetext{
71 "Proposal for a Regulation of the European Parliament and of the Council on serious cross-border threats to health and repealing Decision No 1082/2013/EU", COM/2020/727 final, https://eur-lex.europa.eu/legal-content/EN/TXT/?uri=CELEX:52020PC0727.

72 Tamara Hervey and Anniek de Ruijter, "The Dynamic Potential of European Union Health Law", European Journal of Risk Regulation, 11(4), 2020, op. cit., p. 733.

73 "Regulation (EU) 2021/836 of the European Parliament and of the Council of 20 May 2021 amending Decision No 1313/2013/EU on a Union Civil Protection Mechanism (Text with EEA relevance)", Official Journal of the European Union, 26.5.2021, L 185/1.

74 "COVID-19 lessons learnt: boosting EU civil protection", https://www.europarl. europa.eu/news/nl/press-room/20210208IPR97325/covid-19-lessons-learnt-boostingeu-civil-protection.
} 
više ne suoči sa nedostatkom lične zaštitne opreme, kao što je to bilo tokom početnih faza pandemije. ${ }^{75}$ lako ovaj mehanizam ima mnogo potencijala, postoje mišljenja da je činjenica da je bio nov sprečila da bolje odgovori na zahteve država članica, posebno u prvim fazama pandemije. ${ }^{76}$

\section{Zaključna razmatranja}

Pandemija virusa Kovid 19 pogodila je sve države članice EU, značajno opterećujući nacionalne zdravstvene sisteme i dovodeći do ozbiljnih socijalnih i ekonomskih posledica. Tokom početnog šoka i naknadnog talasa neizvesnosti, države članice su preduzele hitne korake da spreče širenje virusa. Kao rezultat toga, sloboda kretanja ljudi je ograničena, dok su brojne privredne aktivnosti zaustavljene. U tim uslovima vlade država članice bile su primorane da masovno ekonomski intervenišu. Ovi odgovori su, međutim, bili nekoordinisani, dok između država članica nije postojala saradnja u pogledu mera koje će se primeniti u cilju zaštite javnog zdravlja, poput ograničenja prekograničnih putovanja i suspenzije drugih prava i pravila.

Osim toga, primetna je bila inertnost institucija EU što je doprinelo brojnim kritikama evropskog odgovora na pandemiju. lako su evropske institucije relativno brzo aktivirale neke mehanizme za koordinaciju mera na nivou Unije, u ranoj fazi krize ovaj odgovor se pokazao sporim i neadekvatnim. Mnogi su postali svesni da EU nije u stanju da garantuje bezbednost građana, što je posledica specifičnosti njene nadnacionalne prirode, kao i decenijskih ušteda i nedovoljnog ulaganja u zdravstvene i socijalne sisteme nekih država članica. Takođe, zbog poremećaja u globalnim lancima snabdevanja, države članice su se istovremeno suočile sa nestašicom lične zaštitne opreme. Solidarnost na nivou EU bila je otežana i odložena, što je izazvalo raspravu o ulozi EU, kao i o očekivanjima država članica u smislu uzajamne pomoći i podrške. Takođe, unutar Unije javili su se opravdani strahovi da je moguć vrlo nejednak oporavak

75 "A strengthened EU Civil Protection Mechanism endorsed by European Parliament", Brussels, 27 April 2021 European Commission - Press Release, https://ec.europa.eu/ commission/presscorner/detail/en/IP_21_1940.

${ }^{76}$ Anne-Laure Beaussier and Lydie Cabane, "Strengthening the EU's Response Capacity to Health Emergencies: Insights from EU Crisis Management Mechanisms", op. cit., p. 809. 
među državama članicama, što bi dodatno povećalo ekonomsku nejednakost. Pandemija je, prema tome, pokrenula pitanja objektivnih nedostataka u nekim politikama, mehanizmima i instrumentima Unije za rešavanje ove, i sličnih zdravstvenih kriza u budućnosti. Istovremeno, postalo je jasno da ova kriza ne predstavlja pretnju samo zdravstvenim i ekonomskim sistemima država članica, već i institucijama Unije, njenim temeljnim načelima i vrednostima.

Ipak, posebno tokom kasnijih faza krize, došlo je do određenih prilagođavanja instrumenata i mehanizama koja su omogućila institucijama Unije da pruže koherentniji odgovor. Takođe, države članice su pokazale spremnost da rade zajedno na razvoju održivog plana za prevazilaženje posledica ove krize. Naime, na nivou Unije postignut je dogovor o podršci državama članicama koje su najteže pogođene pandemijom sredstvima iz višegodišnjeg budžeta, zahvaljujući programu obnove koji se finansira zajedničkim zaduživanjem.

Imajući u vidu da su političke, ekonomske, bezbednosne i socijalne posledice pandemijske krize međusobno povezane, efikasno upravljanje budućim sličnim krizama na nacionalnom i nadnacionalnom nivou svakako će zahtevati odgovarajuća organizaciona i institucionalna prilagođavanja. Naravno, ona će prvenstveno zavisiti od političke volje država članica i njihove spremnosti da Uniji stave na raspolaganje dodatne resurse. Ipak, teško postignuta solidarnost u ovoj oblasti je neophodna jer od prevazilaženja neposrednih posledica i izazova pandemije, kao i rešavanja dugoročnih strukturnih problema koji stoje iza sve veće nejednakosti među članicama EU, zavisi njena dugoročna održivost.

\section{Literatura}

Beaucillon, Charlotte, "European Solidarity in Times of Emergency: An Introduction to the Special Focus on COVID-19 and the EU", European Papers, Vol. 5, No. 1, 2020.

Beaussier, Anne-Laure and Cabane, Lydie, "Strengthening the EU's Response Capacity to Health Emergencies: Insights from EU Crisis Management Mechanisms", European Journal of Risk Regulation, Vol. 11:4, 2020.

Brooks, Eleanor and Geyerb, Robert, "The development of EU health policy and the Covid-19 pandemic: trends and implications", Journal of European Integration, Vol. 42, No. 8, 2020. 
Brooks, Eleanor, de Ruijter, Anniek and Greer, Scott L., "Covid-19 and European Union health policy: from crisis to collective action", in: Bart Vanhercke, Slavina Spasova and Boris Fronteddu (eds), Social policy in the European Union: state of play 2020 Facing the pandemic, Brussels, 2021.

Celi, Giuseppe, Guarascio, Dario and Simonazzi, Annamaria, "A fragile and divided European Union meets Covid-19: further disintegration or 'Hamiltonian moment'?", Journal of Industrial and Business Economics, 47, pp. 411-424.

Debre, Maria Josepha, Dijkstra, Hylke, "COVID-19 and Policy Responses by International Organizations: Crisis of Liberal International Order or Window of Opportunity?", Global Policy, 2021, pp. 1-12.

Falkner, Gerda, "The EU's current crisis and its policy effects: research design and comparative findings", Journal of European Integration, 38:3, 2016, pp. 219-235.

Hervey, Tamara and de Ruijter, Anniek, "The Dynamic Potential of European Union Health Law", European Journal of Risk Regulation, 11(4), 2020, pp. 726-735.

Jelisavac Trošić, Sanja, Jović-Lazić, Ana, „Ekonomske posledice COVID-19 i mere podrške privredi Republike Srbije", Zarazne bolesti kao globalni bezbednosni izazov - Pandemija COVID-19: stvarnost i posledice, Zoran Jeftić i Mihailo Kopanja (urs), Fakultet bezbednosti, Institut za međunarodnu politiku i privredu, 2020, str. 94-118.

Jović Lazić, Ana i Jelisavac Trošić, Sanja, „Spoljna energetska politika Evropske unije", Evropsko zakonodavstvo, Institut za međunarodnu politiku i privredu, god. XV, br. 55, Beograd, 2016, str. 158-170.

Kai P. Purnhagen, de Ruijter, Anniek, Flear, Mark L., Hervey, Tamara K., and Herwig, Alexia, "More Competences than You Knew? The Web of Health Competence for European Union Action in Response to the COVID-19 Outbreak", European Journal of Risk Regulation, Vol. 11:2, 2020.

Monnet, J., 1978. Memoirs. trans. R. Mayne Garden City: Doubleday \& Company, Navedeno prema: Gerda Falkner The "EU's current crisis and its policy effects: research design and comparative findings", Journal of European Integration, 38:3, 2016, pp. 219-235. 
Rađenovic, Anja and Eckert, Gianna "Upholding human rights in Europe during the pandemic", Briefing, European Parliamentary Research Service, PE 652.085 - September 2020.

Samadashvili, Salome, "A brave, post-COVID-19 Europe", European View, 1/9, 2020, pp. 3-4.

Salvati, Eugenio, "Crisis and Intergovernmental Retrenchment in the European Union? Framing the EU's Answer to the COVID-19 Pandemic", Chinese Political Science Review, Springer, 2021, No. 6, pp. 1-19.

Wolff, Sarah and Ladi, Stella, "European Union Responses to the Covid-19 Pandemic: adaptability in times of Permanent Emergency", Journal of European Integration, 2020, pp. 1025-1040. 


\title{
THE EUROPEAN UNION AND THE COVID-19 VIRUS PANDEMIC-IMMEDIATE RESPONSE AND LONG-TERM MEASURES FOR ADAPTATION TO FUTURE SIMILAR CRISES
}

\begin{abstract}
The COVID-19 pandemic has caused an unexpected global crisis with far-reaching consequences for the health, social and economic systems of most countries. The European Union's initial response was rather disorganized, which was reflected, among other things, in the uncoordinated implementation of blockades or the lack of solidarity between the member states in the procurement of medical and protective equipment. Although this early response to the pandemic revealed the lack of preparedness, cohesion, and solidarity within the Union, the situation has improved significantly in the meantime, with some useful instruments being introduced at the EU level. The aim of this paper is to explore the Union's response to the crisis, as well as the political and economic implications of the pandemic for EU institutions, policies, and actions. What impact did the pandemic have on the political system of the European Union and what measures did it take to respond to the crisis and adapt to the new situation? The basic hypothesis is that, although the crisis posed a major challenge for the EU, its subsequent response to the pandemic shows that it has found the political will and a way to restore cooperation and cohesion at the supranational level. Given that the lessons learned during the crisis can be used to implement the measures needed to advance the European integration process, the pandemic crisis is expected to open up opportunities for closer cooperation among the member states. This is of great importance because, above all, the health crisis has led to a consequent socio-economic crisis, questioning the very foundations and basic principles on which the $\mathrm{EU}$ is based.

Keywords: European Union, the pandemic of COVID-19, response to the crisis, adaptability
\end{abstract}

